\title{
Metafore vir die ontmoeting tussen God en mens en 'n 'swerwende' teoloog se soekend-wandelende reis
}

\begin{tabular}{|c|c|}
\hline \multicolumn{2}{|c|}{$\begin{array}{l}\text { Authors: } \\
\text { Tanya van Wyk }{ }^{1} \\
\text { Andries G. van Aarde }{ }^{2}\end{array}$} \\
\hline \multicolumn{2}{|c|}{$\begin{array}{l}\text { Affiliations: } \\
{ }^{1} \text { Department of Systematic } \\
\text { Theology and Christian } \\
\text { Ethics, Faculty of Theology, } \\
\text { University of Pretoria, } \\
\text { South Africa }\end{array}$} \\
\hline \multicolumn{2}{|c|}{$\begin{array}{l}{ }^{2} \text { Department of New } \\
\text { Testament Studies, Faculty } \\
\text { of Theology, University of } \\
\text { Pretoria, South Africa }\end{array}$} \\
\hline \multicolumn{2}{|c|}{$\begin{array}{l}\text { Note: } \\
\text { Dr Tanya van Wyk is a senior } \\
\text { lecturer in the Department } \\
\text { of Systematic Theology and } \\
\text { Christian Ethics, Faculty } \\
\text { of Theology, University of } \\
\text { Pretoria. Prof. Dr Andries van } \\
\text { Aarde is Professor Emeritus } \\
\text { in the Department of New } \\
\text { Testament Studies, Faculty } \\
\text { of Theology, and Senior } \\
\text { Research Fellow of the } \\
\text { Unit for the Advancement } \\
\text { of Scholarship, University } \\
\text { of Pretoria, South Africa. } \\
\text { This article serves as } \\
\text { an introduction to the } \\
\text { anniversary volume of } \\
\text { HTS Theological Studies, } \\
\text { celebrating the } 15 \text { years } \\
\text { existence of The Reformed } \\
\text { Theological College at the } \\
\text { Faculty of Theology of the } \\
\text { University of Pretoria, South } \\
\text { Africa. }\end{array}$} \\
\hline \multicolumn{2}{|c|}{$\begin{array}{l}\text { Correspondence to: } \\
\text { Tanya van Wyk }\end{array}$} \\
\hline \multicolumn{2}{|c|}{$\begin{array}{l}\text { Email: } \\
\text { tanya.vanwyk@up.ac.za }\end{array}$} \\
\hline \multicolumn{2}{|c|}{$\begin{array}{l}\text { Postal address: } \\
\text { Private Bag X20, Hatfield } \\
\text { 0028, Pretoria, South Africa }\end{array}$} \\
\hline \multicolumn{2}{|c|}{$\begin{array}{l}\text { Accepted: } 25 \text { July } 2015 \\
\text { Published: } 23 \text { Oct. } 2015\end{array}$} \\
\hline \multicolumn{2}{|l|}{ Read online: } \\
\hline 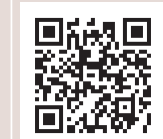 & $\begin{array}{l}\text { Scan this } Q R \\
\text { code with your } \\
\text { smart phone or } \\
\text { mobile device } \\
\text { to read online. }\end{array}$ \\
\hline
\end{tabular}

Metaphors for the encounter between God and humanity and a roaming theologian's reflective journey. This article maps the theology of Christo van der Merwe as a mobilising theology which aided the Netherdutch Reformed Church in Africa (NRCA) in discerning its character, role and purpose. The core of Van der Merwe's theology consists of a journey with God as encountered in the narratives about Jesus and the Spirit told in the Christian Bible. The article shows that the mobilising core of his theology is due to an 'interoperational relationship' between 'knowing and believing'. In the article, the metaphor 'roaming' is used to illustrate this biographical journey as contextual theology which equips pastors with ministerial skills to take care of people who are haunted by trauma.

\section{'Wandel in die Woord': 'Swerf' as metafoor vir die interoperasionele verhouding tussen kennis en vertroue}

Hierdie artikel is ' $n$ refleksie op die teologie van die jubilaris, Doktor J.C. (Christo) van der Merwe. Dit fokus op die rol van metafore in teologiebeoefening vanuit ' $n$ bepaalde perspektief. Die dinamika van metafore in teologiese teorievorming dien as inleiding tot hierdie refleksie op Van der Merwe se teologie. Daarna word kernelemente in sy publikasies uitgelig en krities bespreek. Ten slotte word daar teruggekeer - met die oog op die toekoms - na die teoretiese besinning. 'n Faset van Paul Ricoeur se hermeneutiek van suspisie dien as vertrekpunt in hierdie laaste afdeling (kyk na Ricoeur [1969] 1974:3-26; vgl. Itao 2010:1-17). Dit is naamlik die verrassende positiewe affek wat Ricoeur se dialektiek tussen 'kritiek op geloof' en 'kritiek op kennis' - 'n unheimliche' relasie - tot gevolg het. Hierdie dekonstrukturerende 'kritiek' veronderstel nie 'n negatiewe epistemologie nie, maar eerder ' $n$ negatiewe dialektiek ${ }^{2}$ wat hoop vir die toekoms verteenwoordig te midde van die ervaring van menslike feilbaarheid in die verlede en in die hede.

Christo van der Merwe se beoefening van teologie bestaan uit 'n gesprek met die Bybel, 'n 'wandel in die Woord'. Die begrip 'wandel in die Woord' is ontleen aan die missionale strategie van Patrick Keifert, voorheen bekleër van die Fjelstad Reigstad Chair of Systematic Theology aan die Lutherse Seminarie in St Paul (Minnesota) en tans die president en direkteur van die Research of Church Innovations Institute, met hulle hoofkantoor in Robbinsdale, Minnesota. In Keifert ([2006] 2007:36-37) is die hermeneutiese proses ${ }^{3}$ van só 'n Bybelgebruik uiteengesit en dit het tot 'n gesamentlike publikasie met Pat Taylor Ellison, Dwelling in the Word: A pocket handbook, aanleiding gegee (Keifert \& Ellison 2011). 'n Aantal teoloë in Suid-Afrika ${ }^{4}$ het na aanleiding van riglyne gebaseer op die Church Innovations Institute die Suid-Afrikaanse Vennootskap vir

1.Die Duitse woord "unheimlich" is die antoniem van "heimlich" [huislik] of "heimisch" [inheems] wat familiariteit impliseer. In Engels word 'unheimlich' gewoonlik met 'uncanny' weergegee. Gewoonlik het hierdie Engelse woord die konnotasie van iets wat misterieus is en daarom skrik impliseer. Die 'bang wees' is daaraan toe te skryf dat dit iets onbekend is en nie bekend nie. Natuurlik lei nie alles wat onbekend is tot 'n skrikaffek nie. Daarom dat Sigmund Freud ([1919] [2012] 2014:9) met die fenomeen 'Das Unheimliche' die element van verrassing in gedagte het: wat as die onbekende verwag word en vrees tot gevolg het, blyk op ' $n$ affek te dui wat aanvaarbaar en aangenaam is.

2.Die begrip 'negatiewe dialektiek' is deur die Fankfurtse kritiese filosoof, Theodor W. Adorno, gemunt. Dit opponeer die dialektiese ideaal van Hegel dat sintese tussen konflikterende entiteite positiwisties tot progressie in die menslike kondisie lei. Deur alledaagse sake uit die gewone konvensionele lewe te neem (vgl. Deborah Cook 2001:2) en te wys dat die mens nooit die ideaal van tevredenheid kan bereik nie, wil Adorno ([1966] 1973:150) menswees op'n nie-arriverende reis neem (Adorno [1951] 1974:14). Hierdie soekende wandel - 'the impossibility of a coincidence between the idea and what fulfils it' (Adorno [1951] 1974:127) - is egter nie op sigself negatief nie, maar positief (Cook 2001:5, 14)

3.Kyk Mark Love (2014:9-18) wat die raakpunte tussen Keifert en die hermeneutiek van onder andere Paul Ricoeur en Walter Bruegemann bespreek.

4.Kyk Dames (2007:34-53), Dames, Marais en Van der Walt (n.d.), Hendriks (2007:999-1016), Kok en Niemandt (2009:1-7), Nel (2013:1-7), Niemandt (2010:397-412) en Saayman (2010:5-16).

How to cite this article: Van Wyk, T. \& Van Aarde, A.G., 2015, 'Metafore vir die ontmoeting tussen God en mens en 'n "swerwende" teoloog se soekend-wandelende reis', HTS Teologiese Studies/Theological Studies 71(3), Art. \#3116, 9 pages. http://dx.doi.org/10.4102/hts.v71i3.3116

Copyright: @ 2015. The Authors. Licensee: AOSIS OpenJournals. This work is licensed under the Creative Commons Attribution License. 
Gestuurde Gemeentes gestig. Christo van der Merwe en sy gemeente, die Nederduitsch Hervormde Gemeente Kempton Park-Oos, het 'n aktiewe deelnemer hieraan geword. Die doyen van hierdie missionale denke, Patrick Keifert ([2006] 2007), beskryf die hermeneutiek van 'wandel in die Woord' ook in terme van 'n 'unheimliche' pelgrimsreis:

[It is $]$ a journey filled with learning, growing, discovering, experimenting, visioning, mentoring, and sharing as local churches move from the maintenance of Christendom to innovating missional church in their time and location. (bl. 17)

'Wandel in die Woord' verteenwoordig 'n wisselwerkende hermeneutiese beweging tussen kennis van die Woord en vertroue in God. Wat teologie prakties vir Van der Merwe impliseer, kan gekonseptualiseer word deur die term 'interoperability' in postmoderne inligtingstegnologie as metafoor te gebruik, te wete roaming (kyk Giovanni et al. 2009). Hierdie Engelse woord word gewoonlik in kontekste gebruik waar 'wandel sonder rigting' bedoel word (kyk na die Odhams Dictionary in Smith \& O'Loughlin n.d.:794). Dit is egter ' $n$ term wat metafories in teologie toegepas kan word. In publieke teologie beskryf 'onkonvensionele gelowiges' hulle byvoorbeeld met hierdie term. In Theology Today skryf 'n speelgoedvervaardiger, John Robben (1972):

We ... still consider ourselves Catholics, but no longer Roman ones. We still believe in God, but he's no longer enshrined in the Vatican or a candlelit church ... I guess our Roman days are over and our roaming ones just begun. (bl. 159-160)

Hier word die term 'roaming' met 'n betekenis gevul wat heeltemal anders is as wat Pattana Kitiarsa (2010:585) in sy werk 'Toward a sociology of religious commodification' daarmee bedoel as hy na die modernisme se evangeliserende religieë verwys wat '... aim at roaming and conquering the world ... [taking] the world as their competing grounds'. Die inkleding van die betekenis van 'roaming' is veel nader aan dié van Julian Holloway (2012:203-218), dosent in 'human geography' by die Manchester Metropolitan University, se begrip 'etos van hoop en betrokkenheid' (Holloway 2012:203-218) wanneer hy na teologiese studies as 'nomadic and roaming' verwys (Holloway 2011:385-401) en waar eologie ruimte skep vir 'n 'gesprek met engele' (séance as 'enchanted space') (Holloway 2006:182-187).

In so 'n konteks is die geloofsgemeenskap (na aanleiding van Foucault ${ }^{5}$ ) 'n 'heterotopie'. Van Wyk (2014) stel dit soos volg:

The ecclesia becomes a heterotopia when both space and time are transcended by making hegemony obsolete, and creating space and time for the Other in the here-and-now of this immanent real world. (bl. 6 van 7 )

\footnotetext{
5.Tanya van Wyk (2014:4 van 7) formuleer dit soos volg: "Heterotopia" is an epistemological insight of Foucault ([1967] 1984) and was coined by him in a lecture in 1967 in reference to "space" as place of representation; "utopia" as "space" of the future; and fantasy as "space" that has been sacralised. Foucault endorses the concept "utopia", but very decisively distinguishes between "heterotopia" and "utopia" "Heterotopias" are not "fantasy islands". Heterotopias are spaces, literally "utopia". "Heterotopias" are not "fantasy islands". Heterotopias are spaces, literally "other places" that exist. But it is a space of contrast (cf. Foucault [1967] 1984; Post 2010:100), because heterotopian space is not devoid of utopian ideals - that is, it is not anti-utopian. Rather it is a space wherein utopia becomes visible and tangible, real and traceable.'
}

In die 'kerk as heterotopie' bestaan daar 'n 'interoperasionele verhouding' tussen kennis en vertroue. Die term 'roaming' is ' $\mathrm{n}$ metaforiese uitdrukking van so ' $\mathrm{n}$ 'interoperability'. Die term word deur die Nederlandse praktiese teoloog Ruard Ganzevoort op 'n treffende wyse in sy presidensiële toespraak in 2009 voor die International Academy of Practical Theology in Chicago gebruik om praktiese teologie as 'tracing the sacred' te beskryf:

I especially like the first, archaic meaning of travelling. It suggests that practical theology is itinerant scholarship, which resembles more the roaming through a forest .... This is no plea for unsystematic fuzziness and lack of method. It is an acknowledgment that practical theology belongs to humanities ... [T] he acquisition of knowledge is not simply cumulative, but more often circular ... Neither the human interaction with the sacred nor our analysis of that interaction can be tied securely to previous knowledge but it remains self-critical and open to what is new and unexpected ... When we do theology, we travel the realm of the sacred, trying to understand what is happening there, and letting ourselves be affected by what and whom we encounter ... In that sense, theology itself can even become a spiritual practice in own right. (Ganzevoort 2009:5; beklemtoning bygevoeg)

Om saam met Christo van der Merwe as 'n 'roaming' teoloog te reis, is om saam met hom met die 'Woord te wandel' - dié uitdrukking wat hy as 'spirituele praktyk' in sy geloofgemeenskap, die Nederduitsch Hervormde Kerk van Afrika, gevestig het - en dit is om soos 'n pelgrim in die 'realm of the sacred' te reis. Aanvanklik was dit die Latynse woord peregrinus wat etimologies aanleiding gegee het tot die woord 'pelgrim' (Smith \& O'Loughlin n.d.:794 - in oud-Engels 'pelegrim'). In Augustinus (Civitas Dei 18.51) word die Latyn peregrinus of peregrina in bepaalde kontekste gebruik om op metaforiese wyse na analogie van die Bybelse figure Abel, Abraham én Jesus na die kerk te verwys as 'pelgrims' wat bloot tydelik in hierdie wêreld vertoef en as 't ware aan die verby loop (peregrinari) is (Augustinus [500 CE] 1998). Op 'n 'heterotopiese' wyse word die term peregrina vir Augustinus die kerk as 'stad van God' (vgl. Van Oort 2011) - die ruimte waar kennis én vertroue in 'interoperasionele verhouding' tot mekaar staan. Hierdie artikel verteenwoordig die reis saam met 'n swerwerteoloog - Christo van der Merwe.

Vanuit die perspektief van 'n 'swerwerteoloog' kan die teologie as wetenskap op 'n spesifieke manier beskryf word. In die lig van die spektrum wat bestaan uit enersyds God wat nie vir die mens empiries waarneembaar is nie en andersyds die mens wat die teenwoordigheid van God in die mens se omgewing ervaar, kan teologie beskou word as 'n refleksie op die in-een-geweefde estetiese, rasionele en pragmatiese verhouding tussen God en mens. Teologie is so beskou 'n reflekterende denkweg waar daar nagedink word oor metafore waarmee die ontmoeting tussen God en mens - in die konteks van die mens se omgewing - verwoord word. Hierdie ontmoeting (wat in taal deur middel van metafore voorgestel word) kan met behulp van geykte relasionele verhoudingstaal uitgedruk word. So beskou, is die eienskappe van die teologie die saambondeling van proposisies en die beskrywing van die normatiewe belang 
van sulke stellings wat vir alle mense in enige omgewing geld. Die metafore oor die ontmoetings tussen God en mense kan egter ook op dinamiese wyse kreatief met behulp van nuwe metafore verduidelik word. So beskou, is die teologie 'n vloeiende denkweg. Die omgewing word die ruimte van die ontmoeting en is nie die voorwerp wat aan die menslike wil onderwerp word nie. Die verskeidenheid in menswees is nie net realiteit nie, maar potensialiteit van 'n verskeidenheid ervarings wat die moontlikheid van nuwe ervarings en ontmoetings insluit.

In die sewentigerjare, in 'n boek wat fokus op die 'teologie' (dit wil sê metaforiese spreke) in die Evangelie van Matteus, skryf O'Conner en Jiminez (1977:134-135) dat daardie persone wat op vloeiende wyse dinamies oor God (en Jesus) reflekteer, eintlik besig is om vir hulleself te dink en nie sondermeer deur ander voorgeskryf word nie. Hulle denkweg bestaan uit 'n proses om betekenis vir die lewe te vind deur te besin oor daardie 'groot' metafore wat vanuit die verlede se wysheid kom en wat die sleutels word vir dit wat as wysheid vir sowel die hede as die toekoms kan dien. In hierdie proses van die 'oor-vertaal' van metafore is die vraag of die 'nuwe' die 'oue' vervang (replace), verwerp (reject) sonder om te vervang of aanvaar (accept) deur te verander (changing). Volgens O'Conner en Jiminez (1977:135) vind 'n mens in die Matteusevangelie dat Jesus in verskillende omstandighede 'ou' metaforiese taal oor die God-mens ontmoeting óf vervang óf verwerp sonder om te vervang óf te aanvaar deur te verander.

Die vloeiende teologiese denkweg bestaan vandag steeds uit hierdie spektrum dinamiese potensialiteite. Die hibriditeit van die geykte proposisionele ortodoksie se realiteit bestaan uit slegs twee heteronormatiewe keuses, naamlik om óf die 'oue' te aanvaar óf dit te verwerp. ${ }^{6}$ Ten grondslag gaan dit om mense se ervaring wat in narratiewe oorgelewer word. Die vorm van die narratief varieer. Dit wissel van eenlynspreuke, komplekse dogmatiese proposisies, briewe en traktate, kortverhale by wyse van gelykenisse of langer eposse oor kollektiewe betrokkenheid. Die gelykenis as metaforiese vertelling kry inhoud na aanleiding van voorstellings vanuit die bekende wêreld, vanuit die eksistensiële verwondering van die immanente ontmoeting met die transendente God en/ of die vervreemding wat die verlies van die teenwoordigheid van God vir ('n) gelowige(s) meebring.

Teologiese refleksie fokus op die singewing van hierdie metaforiese ervaringstaal. Wanneer die ervaring dogmaties geyk in taal uitgedruk word, sal die tertium comparationis (punt van vergelyking) tussen immanensie van die menslike hier-en-nou omgewing op 'epiforiese' wyse gedekodeer en hervertaal word (vgl. Wheelwright [1962] 1973:72). Die 'epifoor' in die metafoor getuig van God in direkte relasie met mens en omgewing, soos God wat die animistiese skepper-gewer is wat dit oor sowel gelowiges as goddeloses laat reën. Wanneer die 'diafoor' in die metafoor van die

6.Vir die verskil in epistemologie tussen 'realiteit' en "potentialiteit' (oftewel "a real that is yet to come'), kyk onder andere na Gilles Deleuze en Felix Guattari ([1980] 1987:142) se werk $A$ thousand plateaus. konvensionele ervaring afwyk, ${ }^{7}$ ontmoet die transendensie die immanensie in onverwagte kontrasterende en dinamiese beelde, soos dié van God wat soos 'n hardlopende pa word wat die wegloopkind tegemoetkomend terugverwelkom.

Die teologie van Christo van der Merwe, waaroor hierdie teologiese refleksie ter erkenning van sy teologiese bydrae in die Nederduitsch Hervormde Kerk van Afrika (NHKA) gaan, kan ook nie anders geskied as om funksionele metafore hetsy in 'epiforiese', hetsy in 'diaforiese' vormgewing te identifiseer en te interpreteer nie. Die opdra van 'n feesbundel in die wêreld van die teologie vra dat die geïdentifiseerde metafore hervertaal word in die vorm van 'n biografie. 'n Spesifieke mens se teologiese voetspoor word nagespeur en in oënskou geneem. Dit is hierdie voetspoor wat geïnterpreteer word.

\section{'n Verweefdheid tussen kerk en gemeente}

Die teologiese voetspoor van Christo van der Merwe reflekteer 'n verweefdheid tussen die identiteit van die kerk in die algemeen, die Hervormde Kerk in die besonder en die roeping van die lokale gemeente. Van der Merwe was vir bykans 30 jaar predikant van die Hervormde Kerk se gemeente Kempton Park-Oos. Die verweefdheid van hierdie gemeente se soeke na antwoorde oor hoe om kerk te wees en die Hervormde Kerk (NHKA) se voortdurende pogings om sigself te verstaan en te identifiseer, is die goue draad in sy teologiebeoefening. Dit vloei saam in die stroom van die hoofstroomkerke wat wêreldwyd na plek, rigting, betekenis en identiteit soek. Hierdie breë konteks vorm die bedding van sy teologiese arbeid wat in 2012 in sy aanstelling as hoof van die Hervormde Teologiese Kollege (HTK) aan die Fakulteit Teologie van die Universiteit van Pretoria gekulmineer het. Hiér het hy 'n 'narratief vir kerk-wees vandag', die titel van sy laaste gepubliseerde artikel as hoof van die HTK, as nalatenskap gelaat vir studente wat met hulle teologiese praktykvorming besig is.

Die wyse waarop die gemeente Kempton Park-Oos deel van Van der Merwe se teologiese voetspoor geword het, blyk uit 'n bydrae wat hy gemaak het tot 'n populêrwetenskaplike werk, Stories van hoop, onder redaksie van Malan Nel (2006), 'n praktiese teoloog verbonde aan die Nederduitse Gereformeerde Kerk. Hierin vertel Van der Merwe (2006:135-152) die verhaal van Kempton ParkOos gemeente. Dit is 'n verhaal van hoop wat gebore is uit 'n verlies aan geloofwaardigheid in die samelewing (Van der Merwe 2006:136). In 1996 het die gemeente met 'n gemeentebouproses begin. Ten spyte van wat deur die gemeente as ' $n$ goeie pastorale bediening beskou is, bly die meerderheid onbetrokke en besef die gemeente dat hulle

7.Van Aarde (2014:4 van 11) verduidelik die verskil tussen 'epifoor' en 'diafoor', na aanleiding van Paul Ricoeur (1981:228-247), soos volg. 'The word epiphor is taken fromleiding van Aristet from Aristoteles's [Poetics 1457b.7] notion of "transference" of a name to some "other object [Aristotle 2007]. The idea on "movement" is expressed by phora and "over on to" by 'epi'. An epiphor expresses a similarity. On the other hand, in the diaphor the "movement" is "through", that is 'dia'. A diaphor does not express similarity or resemblance, but the juxtaposition of tenor and vehicle is rather paradoxical by nature.' 
met 'n 'volkskerklike kultuurgodsdiens' (Van der Merwe 2006:137) besig was wat hoofsaaklik op eie oorlewing gerig is. Van der Merwe verwys telkens met waardering na Malan Nel se insigte oor gemeentebou en kerk-wees (Van der Merwe 2006:136-138) en die rigtinggewende vrae, 'Wie is ons?' en 'Waar gaan ons as gemeente heen?' - vrae wat hulle oorsprong by Nel (1994:1-10) het. Daarom was dit gepas dat hierdie gemeente se verhaal juis later in Stories van hoop verskyn. Vir sowel Nel as Van der Merwe is die identiteit en die karakter van die kerk bepalende faktore vir kerk-wees en hulle is in hulle onderskeie kontekste aktief daarmee gemoeid (kyk Nel 1994, 2015; Van der Merwe 1997, 2007, 2012, 2014).

Tydens die gemeentebouproses het die insigte van David Bosch (1991) (Transforming missions) en Steve Sjogren (2003) (Conspiracy of kindness: A refreshing new approach to sharing the love of Jesus with others) by Van der Merwe en die gemeente 'n verskuiwing in denke meegebring. Die voortdurende teologiese besinning oor die karakter en identiteit van die kerk het daartoe gelei dat die gemeente by verskeie gemeenskapsnetwerke betrokke raak en uiteindelik in 2004 die enigste Hervormde gemeente word wat by die 'SuidAfrikaanse Vennootskap vir Gestuurde Gemeentes' aansluit. Dit is 'n ekumeniese ondersteuningsnetwerk van gemeentes wat missionaal in hulle eie onderskeie omgewings betrokke is. Die gemeente waarvan Van der Merwe die predikant is, begin 'n koskas, 'n klerekas en 'n geldkas, en deur skenkings van binne en buite word 'n groot gedeelte van die gemeenskap bedien en hierdie 'kaste' word nie leeg nie (Van der Merwe 2006:139). Die gemeente help om 'n kleuterskool in die 'township' Tembisa te vestig met die oog op Tembisa se kleuterskool se finansiële oorlewing. Hierdie gemeente se verhaal is 'n spieëlbeeld van Van der Merwe se ekumeniese en missionale ekklesiologie en teologie.

\section{'n Prakties-teologiese ekklesiologie: Vrye en simmetriese kommunikasie}

Van der Merwe het 'n reuse bydrae gelewer om die gemeentebouteorie vir die Hervormde Kerk te ontsluit. ${ }^{8}$ Die prakties-teologiese ekklesiologie wat hy ontwikkel, het handaan-hand met gemeentebou geloop en die verweefdheid tussen kerk gemeente wat in sy teologie aanwesig is, is die getuienis daarvan. Dit was vir hom, synde 'n teoloog van die Hervormde Kerk, noodsaaklik om gemeentebou epistemologies te begrond (Van der Merwe 1999:381) en, synde 'n praktiese teoloog, noodsaaklik dat 'n praktiesteologiese ekklesiologiese beskouing as vertrekpunt vir gemeente-opbou moet dien (Van der Merwe 1999:381). Hy formuleer dit soos volg: 'Die kritiese evaluering van ekklesiologieë is noodsaaklik, aangesien gemeentebou telkens weer georiënteer word aan die insig van wat die kerk is' (Van der Merwe 1999:382). In hierdie opsig beskou Van der Merwe kommunikasie as kerneienskap van 'n prakties-teologiese basisteorie. Kommunikatiewe handelinge vereis simmetriese kommunikasie: vrye, gelykwaardige, nie-outoritêre optrede wat vrywaar teen magsmisbruik en instrumentele manipulasie

8.Kyk ook die werk van Beukes (1995)
(Van der Merwe 1999:383; vgl. Dreyer 1995:795). Tog benadruk Van der Merwe (met verwysing na Theuns Dreyer (1991:605), sy voorganger as hoof van die HTK) dat daar'n verskil is in die aard van kommunikasie tussen God en mens, en tussen mens en mens (Van der Merwe 1999:384). Op grond hiervan stel hy 'n basisteorie vir die praktiese teologie voor wat hy soos volg verwoord: 'Praktiese Teologie bestudeer die kommunikatiewe geloofshandelinge van mense, gemeet aan die aanspraak van God op mense, soos dit betuig word in die Skrif' (Van der Merwe 1999:385). Die kommunikatiewe geloofshandelinge van die geloofsgemeenskap moet voortdurend genormeer word vanuit die geloofsrelasie tussen God en mens soos betuig in die Skrif (Van der Merwe 1999:387).

Van der Merwe (1999:387) meen dat die oordrag van geloof in die prediking en diakonale sorg binne interpersoonlike verhoudings plaasvind. 'n Verwronge ampsbeskouing het by verskeie ampsdraers in 'n asimmetriese en manipulerende, outoritêre houding uitgemond. Gemeente-opbou as kern van 'n prakties-teologiese ekklesiologie vra eerder om 'n simmetriese kommunikasieverhouding met gelykheid en die vrye wisseling van dialoogrolle. Hierdie dialoog moet egter altyd vanuit die relasie tussen God en mens gekwalifiseer word. Die koninkryk van God kan nie ongekwalifiseerd aan 'n emansipatoriese praksis gelykgestel word nie (Van der Merwe 1999:388).

Dit sou interessant wees om in 2015, 16 jaar na Van der Merwe hierdie stelling gemaak het, vir Van der Merwe oor sy verstaan van die onderskeid tussen sogenaamde vertikale (tussen God en mens) en horisontale (tussen mens en mens) verhoudings te pols; dit sou interessant wees om by hom te hoor of die Hervormde Kerk in die praktiese teologie (en dalk ook sistematiese teologie) die vertikale ten koste van die horisontale beklemtoon het en om by hom te verneem of hy steeds meen (op die voetspoor van Theuns Dreyer) dat die koninkryk van God nie emansipatoriese praksis impliseer nie.

Gemeentebou is 'n bediening wat moet integreer en koördineer wat in ander bedieninge (soos prediking) plaasvind en dit moet dus by uitstek sensitief daarvoor wees dat die gemeente per definisie 'n kommunikasiesisteem en kommunikasienetwerk is (Van der Merwe 1999:392). Dit is in gemeentebou 'n primêre beginsel om juis oor hierdie wyse aan gemeente-wees te dink. Alle kommunikasie in die gemeente spruit voort uit kommunikasie met God, mekaar en die wêreld. Daarom is gemeentebou diensbaar aan God se doel met God se kerk (Van der Merwe 1999:393). Dit kan nie verstaan word of onderneem word as dit nie in verband met die totale bediening in diens van die kommunikasie van die evangelie plaasvind nie. Dit gaan om die gemeente se effektiewe doelvervulling, wat kan begin plaasvind as die gemeente self die gemeente se bestaansdoel en Godgegewe taak kan verwoord. Vir Van der Merwe (1999:394) '... gaan [dit] nie in die eerste plek oor die oorlewing van 'n gemeente nie'. Hierdie oortuiging het duidelik konkrete inhoud gekry terwyl hy die pad saam met Kempton Park-Oos se Hervormde gemeente gestap het. Dit het die basis gevorm 
van sy navorsing oor die missionale gerigtheid (imperatief) van kerk-wees.

Dit is vir hom belangrik om die onderskeid tussen 'n sistematies-teologiese benadering en 'n prakties-teologiese benadering tot ekklesiologie te maak. Die sistematiese teologie, aldus Van der Merwe (1999:382-382), werk met die oorsprong, eienskappe en identiteit van die kerk, terwyl die praktiese teologie '... na die ontmoetingsgebeure van God se koms na die mens in God se woord deur die diens van die pastorale handelinge vra' (Van der Merwe 1999:382). In sy teologie werk Van der Merwe egter nie kompartementalisties met verskillende vakgebiede nie, al tref hy hierdie onderskeid. In sy epistemologiese teorievorming van gemeentebou (wat die agtergrond van sy hele teologiese oeuvre vorm, later spesifiek in verband met die missionêre of missionale gerigtheid van die kerk - waarna hieronder verwys word) grond Van der Merwe (1997, 1999, 2011, 2014) sy werk op dié van Nel (benewens verwysings vroeër, kyk ook na Van der Merwe \& Beukes 1997:706) wat met die identiteitsvraag van die kerk werk (Nel 1994). Van der Merwe (1999:394) stel self dat dit in gemeentebou gaan oor die begeleiding van die gemeente om die gemeente se identiteit te verstaan. Deur dit te doen, het gemeentebou as 'n selfstandige vak in die praktiese teologie ontwikkel. Dit is duidelik dat die identiteitsvraag nie vir Van der Merwe ' $n$ saak is wat net vanuit een hoek benader kan word nie. Hy maak ruimskoots van die werk van Van Niftrik (1961), Barth (1953), Dingemans (1986) en later Hervormde sistematiese teoloë se werk soos Velthuysen (1988), Koekemoer $(1990,1995)$ en Buitendag (2008) gebruik as hy na die wese en doel van die kerk verwys (kyk Van der Merwe \& Beukes 1997:706-708, 1999:381, 2011:2-3 van 9). Van der Merwe beoefen nie sy teologie in isolasie nie.

\section{Geloofsonderskeiding as sleutelaspek van kerklike identiteit en karakter}

Tydens tafelgesprekke wat hy vanuit die HTK georganiseer het en tydens optredes by gemeentes by geleentheid van die HTK se kursusse vir Voortgesette Teologiese Toerusting (VTT) het Van der Merwe dikwels oor geloofsonderskeiding gepraat -'n onderskeiding in geloof 'oor die dinge waarop dit werklik neerkom'. Op 01 Januarie 2012 het hy die benoeming van die Hervormde Kerk as hoof van die HTK aan die Fakulteit Teologie van die Universiteit van Pretoria aanvaar. Die eerste drie openingsredes wat hy as hoof van die HTK moes aanbied, het saam ' $n$ eenheid in ' $n$ navorsingsartikel gevorm met die tema 'geloofsonderskeiding' (Van der Merwe 2012:1 van 8).

Discerne, die Latynse woord waarvan discernment (onderskeiding) afgelei is, beteken letterlik om in 'n krisis deur toetsing 'n onderskeid tussen goed en kwaad te tref (Marais 2007:34). In die Nuwe Testament word die saak van geloofsonderskeiding op verskeie maniere beskryf. Dit verwys onder andere na die vind van die regte pad (Luk 1:17) of om met die regte insig te leef (Ef 1:8). Oorkoepelend is discernment die vermoë om 'n saak met wysheid te oorweeg voordat 'n besluit geneem word (Marais 2007:35) - 'n oorweging wat geïnspireer word deur 'n gesindheid wat deur Christus gevorm is. Geloofsonderskeiding '... is wanneer nagedink word en sake in die lig van Christus se waardes beoordeel word' (Van der Merwe 2012:7 van 8). Dit is ten diepste ' $n$ keuse vir selfontlediging en diensbaarheid. In die kerkskeuringsproses wat in die kring van die Hervormde Kerk plaasgevind het terwyl Van der Merwe die hoof van die HTK was, beleef hy die verlamming en die interne stryd wat in die Hervormde Kerk aan die orde van die dag was. Te midde van hierdie omstandighede is geloofsonderskeiding vir Van der Merwe lewensbelangrik vir die lewensverhaal van die Hervormde Kerk en die Kerk se soeke na identiteit en selfverstaan. Die keuse 'om as Jesus se dissipels te volhard ... en te midde van die kilheid, koudheid en wreedheid van hierdie wêreld geloof in Christus te leef' (Van der Merwe 2012:7 van 8), is 'n geloofsonderskeiding.

\section{Spiritualiteit en kerk-wees}

As predikant en teoloog van die Hervormde Kerk het Van der Merwe vir verskillende termyne op die Algemene Kommissie van die Nederduitsch Hervormde Kerk van Afrika gedien. Hy was vise-moderator in dié tyd toe die spanning wat op kerkskeuring uitgeloop het hoogspanning bereik het. Na aanleiding van die vrae wat sy teologie bepalend beïnvloed het, naamlik 'Wie is ons?' ,'Hoekom is ons hier' en 'Waar gaan ons heen' (Van der Merwe 2006:136-137; vgl. Nel 1994, 2015), vra hy in en aan die Hervormde Kerk - toe kerkskeuring onafwendbaar begin blyk het: 'Hoe nou vorentoe?' (Van der Merwe 2013:1 van 16).

Vir Van der Merwe is die kerk 'n dinamiese interaksie van mense, nie 'n statiese instituut nie (Van der Merwe 2013:14 van 16; vgl. Van Aarde 2009:52). Dit is daarom vir hom vanselfsprekend dat dit vir die Hervormde Kerk nodig geword het om na die kerkskeuringsproses van 2010 tot 2013 teologies oor die aard en wese - die identiteit en karakter - van die kerk te besin. Die beginpunt van hierdie ekklesiologiese besinning lê vir Van der Merwe (2013:2 van 16) by die kerk se werklikheidsverstaan, wat vir hom 'n hermeneutiese aangeleentheid is. Die kerk se hermeneutiese lense bepaal die kerk se 'is' (aard en wese) en 'doen' (etiek). Die geskiedenis van die Hervormde Kerk word deur 'n deurlopende debat en dialoog oor diversiteit gekenmerk, wat die Kerk se selfverstaan ten opsigte van identiteit en etiek wesenlik beïnvloed het. Deur drie hermeneutiese 'lense', van Armour en Browning (2006), Smith (2011) en Hawkins (2002), te gebruik, bied Van der Merwe (2013:3-10 van 16) 'n antwoord op die vraag, 'Hoe nou vorentoe?'.

Die hermeneutiese lens wat deur Armour en Browning (2006:35-45) ontwikkel is, is 'denksisteme'. Die identifisering van denksisteme kan help om dialoog te fasiliteer omdat daar dan 'n bewussyn van die 'vertrekpunt' van individue binne sisteme is. Dit beteken dat iemand se 'bestemming' ten opsigte van denke beter verstaan kan word. Binne 'n 
sisteem soos die kerk (en kleiner sisteme soos die gemeente) is daar gewoonlik 'n dominante denksisteem wat oorheers en ander denksisteme wat nie geakkommodeer kan word nie (Van der Merwe 2013:4 van 16). Verskille tussen verskillende denksisteme kan tot spanning lei (vgl. Van der Merwe 2013:45-97). Diversiteit is ' $n$ gegewe wat positief aanvaar behoort te word.

Die funksie van Smith (2011:4-14, 60-61) se hermeneutiese lens is om te bepaal waar jy jouself 'spiritueel' bevind (Van der Merwe 2013:5 van 16) en bied 'n logiese antwoord op die vraag oor waarom daar 'n uiteenlopende verskeidendheid kerke en gemeentes is. Spiritualiteit (as 'n begrip en belewenis van God) is iets wat dinamies op verskillende vlakke ontwikkel (eksistensieel) en verskillende kerke se fundamentele idees oor identiteit en karakter word in verskillende spiritualiteite gevind. Smith (2011:xxi) vra: 'What if there is a Christian path that more close follows Jesus than many of us has seen in the past?' Volgens Van der Merwe (2013:5 van 16) gaan dit oor 'n 'algemene posisionering op die geestelike kaart'. Smith se 'integrale' benadering is komprehensief, inklusief en niemarginaliserend. Soveel as moontlik perspektiewe, style en metodes word in 'n netwerk van wedersydse verryking met mekaar in verband gebring (Smith 2011:xxi). Alhoewel Van der Merwe (2013:6 van 16) meen dat hierdie uitgangspunt vir baie in die NHKA bedreigend kan wees, is die doel van 'n integrale kerk om 'n gemeenskap te vestig waar die lede hulle groei progressief kan versnel sover dit die verskillende stadia van begrip in terme van God en verskillende ervarings van God betref. Smith se model probeer die volgende:

\footnotetext{
... [om] ons te help om te verstaan waar ons is en om diegene rondom ons te verstaan en te respekteer met die oog daarop dat die wêreld 'n meer deernisvolle en wyser plek kan word. (Van der Merwe 2013:7 van 13)
}

Volgens Van der Merwe strook dit met die droom wat die Hervormde Kerk het vir die manier waarop dit kerk vir (in) die wêreld wil wees.

Hawkins (2002:20-40) se hermeneutiese lens is gemik op die identifisering van die verskuilde magte wat mense se gedrag bepaal. Die vertrekpunt is die komplekse aard van die bewussyn self en die verband tussen die psigologie van bewussyn, die funksie van die menslike senustelsel en die fisika van die heelal. Hawkins se teorie is dat die menslike verstand soos rekenaarmateriaal werk wat aan 'n reuse databasis gekoppel is (Hawkins 2002:34; vgl. Van der Merwe 2013:10 van 16). Die databasis is die menslike bewussyn, waarby die individuele waarneming of uitdrukking ingebed is en op kort kennisgewing tot elkeen se beskikking is. Die databasis oorstyg individuele bewussyn. Van der Merwe is van mening dat Hawkins se studie belofte inhou as 'n hulpmiddel in geestelike groei sover dit gevorderde vlakke van bewussyn betref (Van der Merwe 2013:10 van 16).

In die lig van hierdie hermeneutiese besinning oor die Hervormde Kerk se werklikheidsverstaan te midde van en direk na 'n kerkskeuringsproses het die Kerk volgens Van der Merwe bepaalde verantwoordelikhede. 'n Effektiewe benutting van diversiteit (Van der Merwe 2013:11 van 16) beteken die ontwikkeling van 'n atmosfeer van verdraagsaamheid en die beoefening van sisteemsensitiwiteit. 'n Integrale benadering tot kerk-wees vertrek vanuit 'n integrale verstaan van die Bybel wat al die dele van die Bybel in 'n 'verstaanbare verslag' saamweef - daar behoort gewaak te word teen die versoeking om die geloofsbelewenisse van die mense van die Bybel in proposisies vas te vang (Smith 2011:74; vgl. Van Aarde 2009:28). Van der Merwe (2013) pleit ook vir 'n bewussyn van wetenskaplike insigte in die identifisering van hermeneutiese lense:

'n Teologie wat die wetenskap in berekening bring erken ook
dat die kerk tans in 'n fase van deïnstitusionalisering is. Dit
beteken nie dat die evangelie verwerp word ten gunste van die
sekulêre, agnostiese of ateïstiese beskouinge dat God, geloof en
die kerk alreeds dood is nie ... Die ampte moet funksioneel wees,
diensgeoriënteerde leierskap wat mense fasiliteer en lei om
God en ander met hulle diverse gawes te dien ... 'n legalistiese
ekklesiologie moet plek maak vir ['n] evangeliese perspektief op
die kerk ... die menslikheid van die kerk moet erken word en die
klem [moet] val op 'n lewe wat deur die Gees van God beheers
word. (bl. 13 van 16)

Deur die drie lense as hulpmiddels en as gereedskap of toerusting vir die NHKA se pad vorentoe aan te bied, bly Van der Merwe by sy teologiese selfopgelegde taak. Dit is naamlik om telkens opnuut saam met die kerk oor die uitdagings van kerk-wees na te dink.

\section{Missionale kerk-wees: Verandering van die kerk (ook die NHKA) se selfverstaan}

Soos in die inleiding tot hierdie huldigingsartikel daarop gewys is, kan Van der Merwe se teologiese selfopgelegde taak oorkoepelend beskryf word as 'n pelgrimstog na ekklesiologiese identiteit te midde van paradigmaskuiwe en veranderende kontekste waarbinne die kerk kerk is (Van der Merwe \& Beukes 1997; Van der Merwe 2011, 2014).

Hy is opreg bekommerd oor en soek na oorsake vir dalende lidmaatgetalle (oftewel, 'n gebrek aan groei) binne die Hervormde Kerk (Van der Merwe \& Beukes 1997:705721). In vroeëre navorsing oor die funksionering van die Hervormde Kerk het Van der Merwe bepaalde tendense opgemerk wat daarop neerkom dat die Kerk te veel tyd en aandag aan eie oorlewing en voortbestaan bestee. In 1997 skryf hy dat dit neerkom op 'n gebrek aan 'n missionêre gerigtheid. Hy was van mening dat die Kerk se 'wese en doel dikwels misgekyk' is (Van der Merwe \& Beukes 1997:705). Vir hom hou dit verband met die kerk se institusionele karakter waarin 'beweging' - wat 'n integrale deel van kerkwees is - verlore gegaan en selfs verdwyn het. Hy pleit vir'n grondige teologiese besinning oor die wese van die kerk wat nie net 'simptome' sal 'dokter' nie (Van der Merwe \& Beukes 1997:707). In hierdie opsig blyk dit weer duidelik dat Van der 
Merwe teorie met praktyk in verband bring om sodoende 'n verbeterde praktyk te help vestig.

Christelike gestuurheid gee uitdrukking aan die dinamiese verhouding tussen God en die wêreld (Van der Merwe \& Beukes 1997:708). In hierdie vroeëre navorsing oor Christelike gestuurdheid tref hy die onderskeid tussen 'sending' en 'sendings'. Die enkelvoud beklemtoon die missio Dei: dit God se self-openbaring. Die meervoud verwys na die missiones ecclesiae: dit is die missionêre bedrywighede van die kerk. In 2011 benadruk hy steeds die gestuurdheid van die kerk (en dié van die Hervormde Kerk), maar hy gebruik nou die byvoeglike naamwoord 'missionaal' en nie meer 'missionêr' nie. Die gebruik van 'missionaal' het volgens Van der Merwe (2011:5 van 9) die hele diskoers waarbinne na 'kerk en sending' verwys is, in 'n nuwe konseptuele raamwerk geplaas. Die bewussyn het algaande gegroei dat die uitdrukking 'kerk en sending' 'n digotomie kan veronderstel waarin een meestal voorrang voor die ander kry. Die konsep 'missionale kerk' veronderstel egter 'n ekklesiologie waarin die kerk se wese missionêr is. Hiervolgens is elke konteks 'n missionale konteks en elke gemeente is ' $n$ missionale gemeente wat self verantwoordelik is en verantwoordelikheid aanvaar om aan God se sending deel te neem (Van der Merwe 2011:5 van 9; vgl. Van Gelder 2007:27). Van der Merwe (2011:3 van 9) se hele uitgangspunt is egter nog meer komprehensief: 'My vertrekpunt is dat teologie in wese missionaal is.' Dit noodsaak 'n missionale metodologie, met missio Dei as vertrekpunt. Missio Dei vloei vanuit God se wese: God se liefde en God se barmhartigheid, God se vergewensgesindheid in terme van God se geregtigheid wat onbegrens is. God is in God se wese self 'sending' (Van der Merwe 2011:4 van 9).

Ook in missionale teologie word geloofsonderskeiding beklemtoon (Van der Merwe 2011:4 van 9; vgl. Van der Merwe 2012). Hierbinne staan dialogiese hermeneutiek sentraal. Dit is duidelik hoekom dit vir Van der Merwe vanselfsprekend is dat vrye, simmetriese kommunikasie lewensbelangrik vir kerk-wees is. Hy stel dit soos volg:

Missionale teologie impliseer ' $n$ onderskeidingsproses wat plaasvind wanneerons gehoorsaam deelneemaan'ntransformasieaksie en - diens op verskillende vlakke: persoonlik, ekklesiologies, op sosiale gebied, ten opsigte van die ekologie, asook op die gebied van die wetenskap ... 'n doenende, bevrydende, transformatiewe teologie wat uitloop op strategievorming, implementering en 'n evaluasie van vooruitgang; ' $n$ teologiese handeling. (Van der Merwe 2011:6 van 9)

Transformasie in die proses van 'wandel in die Woord' vorm vir Van der Merwe 'n teologiese refrein. In sy 2014-artikel getitel "n Narratief vir kerk-wees vandag' (Van der Merwe 2014) laat hy steeds die teologiese spore van mede-soeke (saam met die Hervormde Kerk en die algemene kerk) na die kerk se selfverstaan te midde van paradigmaskuiwe:

Sover dit die kerk en sending raak, is 'n nuwe paradigma nodig, 'n nuwe visie van die werklikheid, ' $n$ fundamentele verandering van denke, persepsies en waardes. Dit op sigself verg dat gelowiges deur eerlike en indringende vrae oor God se doel met die kerk, in die geloof sal onderskei wat God se doel is, en om dan, op grond van geloofsonderskeiding, verskillend te handel ooreenkomstig met wat God van die kerk verwag. (bl. 3 van 13)

Dit is nie 'n 'beweging' (sy eie verwysing) wat tot ' $n$ einde kom nie (kyk weer na die inleidingsgedeelte). Dit is die eis aan 'n Reformatoriese kerk wat '... nie mag stagneer nie, want dit het nie gearriveer nie en kan nooit die laaste woord spreek nie' (Van der Merwe 2011:1 van 9). Dit is juis in hierdie sin dat daar volgens hom nog 'n onafgehandelde taak op die Hervormde Kerk wag (Van der Merwe 2011:8 van 9) - weereens potensialiteit eerder as realiteit. Die uitdaging vir die NHKA is die beliggaming van missionale kerkwees. Waar gemarginaliseerdes in die Kerk ter sprake kom en die missio Dei beliggaam moet wees, is daar dikwels verdere marginalisasie.

In hierdie sin kan mens die 'profetiese stem' tot Van der Merwe se teologiese voetspoor toevoeg. Hy is uitgesproke oor die kwessies waaroor die Hervormde Kerk behoort te besin, iets waarvoor daar dikwels teruggedeins word. Situasies of gevalle waar daar vir die Hervormde Kerk nog 'n uitdaging of twee ten opsigte van die beliggaming van missionale kerk-wees wag, is volgens Van der Merwe (2011:8 van 9) die debat oor gays. Hy noem twee ander kwessies, te wete rassisme en ekumeniese betrokkenheid. Sedert sy dienstydperk in die moderatuur van die NHKA het die Kerk inderdaad gedurende die periode 2013 tot 2015 reuse spronge rakende hierdie sake geneem.

Dit sal interessant wees om vir Van der Merwe te pols oor wat hy nou dink die grootste uitdaging ten opsigte van die beliggaming van 'n missionale karakter in die Hervormde Kerk is. Miskien bied hy tog ' $n$ implisiete antwoord op hierdie vraag. In die 2014-artikel skryf hy dat dit die kerk (in die algemeen) se bestaansdoel is om deel te neem aan dit waarmee God in God se wêreld besig is (Van der Merwe 2014:9 van 13). Hy benadruk dat die kerk nie bloot daarna moet strewe om in die eie institusionele behoeftes te voorsien nie. Die taak van die teologie (en die kerk) behoort te wees om mense korporatief en individueel te bemagtig om 'getrouer getuies van Christus en sy koninkryk in hulle huise, woonbuurte, werkplekke en in die gemeenskap as geheel' te wees (Van der Merwe 2014:10 van 13). Dit ís inderdaad 'n uitdaging aan die Hervormde Kerk - 'n Kerk wat geskeur het en met 'n spreekwoordelike handjievol mense oor die volgende vrae moet besin: 'Wie is ons?', 'Hoekom is ons hier?' en 'Waarheen is ons op pad?'.

Die krisis is nie meer een van oorlewing nie. Dit is een van identiteit (Van der Merwe 2014:10 van 13) - 'n identiteit van 'n roaming church binne 'n gesekulariseerde wêreld, gekenmerk deur wat Shelly Rambo (2010:180) beskryf as die 'roaming character of the suffering'. Met verwysing na Vietnam, Desert Storm en Irak (m.a.w. 11 September 2001), sê Rambo (2010):

Trauma begins with an event or series of events that are too much to bear. The experience is beyond the 'edge' of what is possible to perceive and to respond to, beyond what we are able to include in our identities, as individuals or as communities. (bl. 18) 
In terme van kontekstuele teologie is dit 'n versoeking van sommige predikante - in hulle strewe om, in die woorde van William Willimon (2002:56), 'useful' en 'effective' te wees die rol van 'n 'surrogate social activist' oor te neem. Christo van der Merwe se profetiese rol in die Hervormde Kerk het nie aan hierdie versoeking toegegee nie. Hy is inderdaad ' $n$ 'kontekstuele teoloog' en wat wel van hom hieroor gesê kan word, word treffend deur Willimon (2002) geformuleer:

The pastor ought to spend more effort in equipping the saints to speak truth to power than in being free floating, carping social critic ... Pastors ought not to be distracted from the more mundane and often more difficult work of forming an entire prophetic community in the church by their sometimes more visible and appealing work of roaming about the community and appearing as prophets before the media to pontificate on various 'justice issues'. (bl. 56)

\section{Die 'roaming teoloog'}

Christo van der Merwe se kontekstuele teologie' verteenwoordig 'n charismatiese 'wandel in die Woord'. In die inleiding tot hierdie huldigingsartikel is daar na Paul Ricoeur se 'negatiewe dialektiek' met die unheimliche positiewe konnotasie van 'kritiek op geloof' en 'kritiek op kennis' verwys. Van der Merwe se 'kennis van die Woord' en sy 'vertroue in God' as die openbaarder van die Woord getuig van sy diep besef van sy kerklike geloofsfamilie se feilbaarheid in die verlede, maar dit getuig ook van Julian Holloway se etos van hoop en betrokkenheid. Vir hom is die geloofsgemeenskap 'enchanted space' - wat Holloway (2006:182-187) séance noem, en wat ons die pelgrim se gesprek met die Heilige Gees noem. Daarom verteenwoordig sy teologie Holloway (2011:285-401) se elemente van 'nomadic and roaming' - wat Ganzevoort (2009:5) as die reis binne die 'realm of the sacred' beskryf en waar die teologie 'n praktyk van spiritualiteit in eie reg word.

Die Sweedse teoloog Sigurd Bergmann, wat in sy publikasie reeds soveel oor hierdie 'ruimtes van spiritualiteit' geskryf het, sê dat die Heilige Gees nie net lewe aan die mens as skepsel gee nie maar ook aan die ruimte waar die spirituele mens aanwesig is (Bergmann 2003:28). Hy sê ook: 'It is especially the places which are seen as profane in a culture that attract the interest of contextual theologians' (Bergmann 2003:28). Die volgende opmerkings oor die wandel in die God van die Woord in die lewe van Jesus van Nasaret van Galilea is treffend:

The human God of the Gospels ... was surprisingly restless and placeless. He [God/Jesus] was either on a pilgrimage or was roaming about, or temporarily staged with someone, or he [God/Jesus] was simply a down-and-out. The poor and badly reputed northern part of the country [Galilee] was unexpectedly the starting point for the missionary's journey to the centre of power ... It does not seem to become calmer and more place-bound with the Holy Spirit either ... (Bergmann 2003:26-29; beklemtoning bygevoeg)

Christo van der Merwe (2014:11 van 13) se voorstel vir 'n 'narratief vir kerk-wees vandag' vra dat gelowiges hulle verskillende verhale van eie 'wandel in die Woord' - met God, met Jesus van Nasaret, met die Heilige Gees - vertel. 'n Narratief is 'n lens vir die gemeente se deelname aan die missio Dei. Christo van der Merwe is nie net deel van die kerk se lewensverhaal nie. Hy het die kerk gehelp om 'n outentieke verhaal te vertel en dit só te doen dat 'n oop einde nog vir die kerk beskore is.

\section{Erkenning}

\section{Mededingende belange}

Die outeurs verklaar hiermee dat hulle geen finansiële of persoonlike verbintenis het met enige party wat hulle voordelig of nadelig in die skryf van hierdie artikel kon beïnvloed nie.

\section{Outeursbydrae}

A.G.v.A. (Universiteit van Pretoria) is HTS se hoofredakteur en is verantwoordelik vir die inleiding en die redaksionele versorging van hierdie artikel en T.v.W. (Universiteit van Pretoria) het die navorsing vir hierdie artikel gedoen en die basisteks voorberei.

\section{Literatuurverwysings}

Adorno, T.W., [1966] 1973, Negative dialectics, transl. E.B. Ashton, Continuum, New York, NY.

Adorno, T.W., [1951] 1974, Minima moralia: Reflections from damaged life, transl. E.F.N. Jephcott, Verso, London.

Aristotle, 2007, The poetics, transl. I. Bywater, in J. Garret, 'Aristotle on metaphor: Excerpts from "Poetics" and "Rhetoric", viewed 17 March 2014, from http:// people.wku.edu/jan.garrett/401s07/arismeta.htm

Armour, M.C. \& Browning, D., 2006, Systems-sensitive leadership: Empowering diversity without polarizing the church, College Press, Joplin, MO.

Augustinus [5 C.E.] 1998, De Civitate Dei contra paganos, The city of God against the pagans, transl. R.W. Dyson, Cambridge University Press, New York, NY.

Barth, K., 1953, Kirchliche dogmatik, IV/1, EVZ, Zürich.

Bergmann, S., 2003, God in context: A survey of contextual theology, Ashgate Publishing, Burglington, VT.

Beukes, M.J. du P., 1995, 'Evaluering van verskillende gemeenteboumodelle met die oog op die daarstelling van ' $n$ eie model vir die Nederduitsch Hervormde Kerk van Afrika', HTS Teologiese Studies/Theological Studies 51(3), 806-824. http://dx.doi. org/10.4102/hts.v51i3.1438

Bosch, D., 1991, Transforming mission: Paradigm shifts in theology of mission, Orbis Books, Maryknoll, NY.

Buitendag, J., 2008, 'Ecclesia reformata semper reformanda: Die ongemaklike eis', HTS Teologiese Studies/Theological Studies 64(1), 123-138. http://dx.doi. org/10.4102/hts.v64i1.7

Cook, D., 2001, 'Adorno, ideology and ideology critique', Philosophy \& Social Criticism 27(1), 1-20. http://dx.doi.org/10.1177/019145370102700101

Dames, G.E., 2007, 'new frontiers for mission in the postmodern era: Creating sustainable communities partnership for missional church', Missionalia 35(1), 34-53.

Dames, G., Marais, F. \& Van der Walt, P. n.d., 'Gemeentes wat hulle roeping ontdek', viewed 25 July 2015, from www.gemeentes.co.za/.../Gemeentes\%20wat\%20hulle

Deleuze, G. \& Guattari, F., [1980] 1987, A thousand plateaus, transl. B. Massumi, University of Minnesota Press, Minneapolis, MN.

Dingemans, G.D.J., 1986, In het leerschool van het geloof, Kok, Kampen.

Dreyer, T.F.J., 1991, 'Eerste treë in die praktiese teologie: Waarheen?', HTS Teologiese Studies/Theological Studies 47(1), 597-608. http://dx.doi.org/10.4102/hts. v47i3.2420

Dreyer, T.F.J., 1995, 'Implikasies van die kommunikatiewe handelingsteorie vir 'n prakties-teologiese perspektief op die ekklesiologie', HTS Teologiese Studies/ Theological Studies 51(3), 792-805. http://dx.doi.org/10.4102/hts.v51i3.1435

Freud, S., [1919] [2012] 2014, Das Unheimliche, Europäischer Literaturverlag, Bremen.

Ganzevoort, R.R., 2009, 'Forks in the road when tracing the sacred: Practical theology as hermeneutics of lived religion', Presidential address International Academy of Practical Theology, Chicago, 03 August, viewed 06 July 2015, from www.ia-pt.org/ wp-content/uploads/2011/.../presidentialaddress2009.pdf

Giovanni, F., De Furio, I., Russo, R., Romano, L. \& Ceccarini, F., 2009, Service-level roaming: A new virtual environment concept, ProQuest, Ann Aebor, MI.

Hawkins, D.R., 2002, Power vs force: The hidden determinants of human behaviour, Hay House, Inc., Carlsbad, CA. 
Hendriks, H.J., 2007, 'Missional theology and social development', HTS Teologiese Studies/Theological Studies 63(3), 999-1016, http://dx.doi.org/10.4102/hts. v63i3.244

Holloway, J., 2006, 'Enchanted spaces: The séance, affect and geographies of religion', Annals of the Association of American Geographers 96(1), 182-187. http://dx.doi. org/10.1111/j.1467-8306.2006.00507.x

Holloway, J., 2011, 'Spiritual life', in V.J. Del Casino, M. Thomas, P. Cloke \& R. Paneli (eds.), A companion to social geography, pp. 385-401, Wiley-Blackwel, Malden, MA. http://dx.doi.org/10.1002/9781444395211.ch22

Holloway, J., 2012, 'The space that faith makes: Towards a (hopeful) ethos of engagement', in J. Holloway (ed.), Religion and place: Landscape, politics and piety, pp. 203-218, Springer Publishing, Dordrecht.

Itao, A.D.S., 2010, 'Paul Ricoeur's hermeneutics of symbols: A critical dialectic of suspicion and faith', Kritike 4(2), 1-17.

Keifert, P., [2006] 2007, We are here now: A new missional era-a missional journey of spiritual discovery, Allelon Publishers, Eagle, ID.

Keifert, P. \& Ellison, P.T., 2011, Dwelling in the word: A pocket handbook, Church Innovations Institute, Robbinsdale, MN.

Kitiarsa, P., 2010, 'Towards a sociology of religious commodification', in B.S. Turner (ed.), The New Blackwell companion to the sociology of religion, pp. 563-590, Blackwell Publishing, Oxford. http://dx.doi.org/10.1002/9781444320787.ch25

Koekemoer, J.H., 1990, 'Die na-binne of introverte gerigtheid van die Kerk: Kerk en wêreld 2000', HTS Teologiese Studies/Theological Studies 46(6), 708-715. http:// dx.doi.org/10.4102/hts.v46i4.2365

Koekemoer, J.H., 1995, 'Die kerk as dogmatiese gebeure: 'n Dogmatiese perspektief', HTS Teologiese Studies/Theological Studies 51(3), 595-603. http://dx.doi. org/10.4102/hts.v51i3.1416

Kok, J. \& Niemandt, C.J.P., 2009, '(Re)discovering a missional-incarnational ethos', HTS Teologiese Studies/Theological Studies 65(1), Art. \#274, 7 pages. http://dx.doi. org/10.4102/hts.v65i1.274

Love, M., 2014, 'Missional interpretation: The encounter of a Holy God through a living text', Missio Dei: A Journal of Missional Theology and Praxis 5(1), 9-18.

Marais, F., 2007, God praat, leef luisterryk, Bybelkor, Wellington.

Nel, M., 1994, Gemeentebou, Orion Uitgewers, Halfway House.

Nel, M., 2006, Stories van hoop: Gemeentes wat in hulle konteks 'n verskil maak en hoop bring, Christelike Uitgewersmaatskappy, Vereeniging.

Nel, M., 2015, Identity-driven churches; Who are we, and where are we going?, Biblecor, Wellington.

Nel, M.J., 2013, 'The influence of dwelling in the Word within the Southern African Partnership of Missional Churches', Verbum et Ecclesia 34(1), Art. \#778, 7 pages. http://dx.doi.org/10.4102/ve.v34i1.778

Niemandt, C.J.P., 2010, 'Five years of missional church: Reflections on missional ecclesiology', Missionalia 38(3), 397-412.

O'Conner, D. \& Jiminez, J., 1977, The images of Jesus: Exploring the metaphors in Matthew's Gospel, Winston, Minneapolis, MN.

Rambo, S., 2010, Spirit and trauma: A theology of remaining, Westminster John Knox Press, Louisville, KY.

Ricoeur, P., [1969] 1974, 'Existence and hermeneutics', transl. K. McLaughlin, in D. Ihde (ed.), The conflict of interpretations, pp. 3-26, Northwestern University Press, Evanston, IL.

Ricoeur, P., 1981, 'The metaphorical process as cognition, imagination, and feeling', in M. Johnson (ed.), Philosophical perspectives on metaphor, pp. 228-247, University of Minnesota Press, Minneapolis, MN.
Robben, J., 1972, 'Roaming Catholics', Theology Today 29(2), 159-160. http://dx.doi. org/10.1177/004057367202900206

Saayman, W.A., 2010, 'Missionary or missional? A study in terminology', Missionalia 38(1), 5-16.

Sjogren, S., 2003, Conspiracy of kindness: A unique approach to sharing the love of Jesus, Bethany House Publishers, Bloomington, MN.

Smith, A.H. \& O'Loughlin, J.L.N. n.d., Odhams dictionary of the English language, Odhams Books Limited, Long Acre.

Smith, P.R., 2011, Integral Christianity: The spirit's call to evolve, Paragon House, St. Paul, MN.

Van Aarde, A.G., 2009, 'Theological trends in our postsecular age', Verbum et Ecclesia 30(3), Art. \#178, 8 pages. http://dx.doi.org/10.4102/ve.v30i3.178

Van Aarde, A.G., 2014, 'Pragmatic dimensions in parable research and the divine economy of the basileia', HTS Teologiese Studies/Theological Studies 70(1), Art. \#2688, 11 pages. http://dx.doi.org/10.4102/hts.v70i1.2688

Van der Merwe, J.C., 1999, "n Prakties-teologiese begronding vir gemeentebou as kommunikatiewe handeling in diens van die evangelie', HTS Teologiese Studies/ Theological Studies 55(2/3), 380-399. http://dx.doi.org/10.4102/hts.v55i2/3.1589

Van der Merwe, J.C., 2006, 'Al hoe meer om te gee ...', in M. Nel (ed.), Stories van hoop: Gemeentes wat in hulle konteks'n verskil maak en hoop bring, pp. 135-152, Christelike Uitgewersmaatskappy, Vereeniging.

Van der Merwe, J.C., 2007, 'Die eenheid wat tussen Christene bestaan', Die Hervormer $100(6), 5-6$.

Van der Merwe, J.C., 2011, 'Missionale gemeentes in die Nederduitsch Hervormde Kerk van Afrika: Teologies verantwoord', HTS Teologiese Studies/Theological Studies 67(3), Art. \#1094, 9 pages. http://dx.doi.org/10.4102/hts.v67i3.1094

Van der Merwe, J.C., 2012, "n Homilie oor geloofsonderskeiding in 'n akkoord van drie', HTS Teologiese Studies/Theological Studies 68(1), Art. \#1259, 8 pages. http://dx.doi.org/10.4102/hts.v68i1.1259

Van der Merwe, J.C., 2013, 'Lense op spiritualiteit en kerkwees: Die pad vorentoe vir die Nederduitsch Hervormde Kerk van Afrika (NHKA)', HTS Teologiese Studies/ Theological Studies 69(1), Art. \#1988, 16 pages. http://dx.doi.org/10.4102/hts. v69i1.1988

Van der Merwe, J.C., 2014, "n Narratief vir kerk-wees vandag', HTS Teologiese Studies/ Theological Studies 70(1), Art. \#2699, 13 pages. http://dx.doi.org/10.4102/hts. v70i1.2699

Van der Merwe, J.C. \& Beukes, M.J., 1997, 'Die missionêre gerigtheid van die kerk', HTS Teologiese Studies 53(3), 705-721. http://dx.doi.org/10.4102/hts.v53i3.1690

Van Gelder, C., 2007, 'Missiology and the missional church in context', in C. van Gelder (ed.), The missional church in context: Helping congregations develop contextual ministry, pp. 12-43, Wm B. Eerdmans, Grand Rapids, MI.

Van Niftrik, G.C., 1961, Kleine Dogmatik, Callenbach, Nijkerk.

Van Oort, J., 2011, 'Augustinus' geschrift "De stad van God" (De civitate Dei): Een introductie tot de belangrijkste themata', HTS Teologiese Studies/Theological Studies 67(1), Art. \#1017, 9 pages. http://dx.doi.org/10.4102/hts.v67i1.1017

Van Wyk, T., 2014, 'Church as heterotopia', HTS Teologiese Studies/Theological Studies 70(1), Art. \#2684, 7 pages. http://dx.doi.org/10.4102/ hts.v70i1.2684

Velthuysen, G.C., 1988, 'Die wese van die kerk: 'n Teologiese antwoord op 'n filosofiese vraag', HTS Teologiese Studies/Theological Studies 44(2), 489-513. http://dx.doi. org/10.4102/hts.v44i2.2224

Wheelwright, P., [1962] 1973, Metaphor and reality, Indiana University Press, Bloomington, IN.

Willimon, W.H., 2002, Pastor: The theology and practice of ordained ministry, Abingdon Press, Nashville, TN. 